\title{
Induksi Mutasi Tanaman Leunca (Solanum nigrum L.) untuk Meningkatkan Keragaman Kandungan Tanin
}

\author{
Induced Mutation in Black Nightshade (Solanum nigrum L.) \\ to Increase Diversity of Tannin Content
}

\author{
Siti Hartati Yusida Saragih ${ }^{1}$, Syarifah Iis Aisyah ${ }^{2 *}$, dan Sobir ${ }^{2}$ \\ 'Program Studi Pemuliaan dan Bioteknologi Tanaman, Sekolah Pascasarjana, Institut Pertanian Bogor \\ ${ }^{2}$ Departemen Agronomi dan Hortikultura, Fakultas Pertanian, Institut Pertanian Bogor \\ (Bogor Agricultural University), Jl. Meranti, Kampus IPB Darmaga, Bogor 16680, Indonesia
}

Diterima 12 Januari 2018/Disetujui 29 Januari 2019

\begin{abstract}
Black nightshade (Solanum nigrum L.) is one of the indigenous vegetables in Indonesia. The fruit of this vegetable is green and has bitter taste because of its tannin content. The objectives of this study were to get lethal dose $50\left(L D_{50}\right)$, diversity and to obtain candidates of mutant plants with high and low tannin content in young fruit and ripe fruit of black nightshade. The research was conducted at Pasir Kuda experimental station, Bogor; National Nuclear Energy Agency (BATAN), Jakarta; and postharvest laboratory of the Center for Tropical Horticulture Studies (PKHT IPB), Bogor, from December 2016 to July 2017. Black nightshade accessions of SN 20 and SN 29 were irradiated using doses of 0, 100, 150, 200, and 250 Gy of gamma ray. The $L D_{50}$ values for $S N 20$ and SN 29 were 171.944 Gy and 190.949 Gy, respectively. The analysis of tannin content was performed based on permanganate method by titration using potassium permanganate. The results showed that the highest tannin content of green stage fruit was found in SN20D3.5 with 200 Gy dose and the lowest was found in SN29D1.5 with 100 Gy dose. The highest tannin content of ripe fruit was found in SN20D4.6 with dose of 250 Gy and the lowest was found in SN20D3.1 with dose of $200 \mathrm{~Gy}$. Recommended tannin content for black nightshade is the low tannin content.
\end{abstract}

Keywords: diversity, gamma ray, indigenous vegetable, irradiation, $L D_{50}$

\section{ABSTRAK}

Leunca (Solanum nigrum L.) adalah salah satu sayuran asli di Indonesia. Sayuran ini memiliki buah hijau dan rasa sepat karena adanya kandungan tanin. Tujuan dari penelitian ini adalah untuk mendapatkan Lethal Dosis $50\left(L D_{50}\right)$, mengetahui keragaan tanaman dan memperoleh kandidat mutan leunca yang memiliki kandungan tanin yang tinggi dan rendah pada buah muda dan buah tua. Penelitian dilaksanakan di kebun percobaan Pasir Kuda, Bogor, di Badan Tenaga Nuklir Nasional (BATAN) Pasar Jumat, Jakarta; dan di Laboratorium Pascapanen Pusat Kajian Hortikultura Tropika (PKHT), Bogor, dari bulan Desember 2016 hingga Juli 2017. Buah leunca aksesi SN20 dan SN29 diiradiasi pada dosis 0, 100, 150, 200, dan 250 Gy. Nilai LD $D_{50}$ leunca untuk SN 20 dan SN 29 masing-masing adalah 171.944 Gy dan 190.949 Gy. Hasil penelitian menunjukkan bahwa identifikasi kandungan tanin buah muda leunca tertinggi dihasilkan oleh aksesi SN20D3.5 dengan dosis 200 Gy dan kandungan tanin terendah pada aksesi SN29D1.5 dengan dosis 100 Gy. Kandungan tanin buah tua tertinggi dihasilkan oleh aksesi SN20D4.6 dengan dosis 250 Gy dan kandungan tanin terendah terdapat pada aksesi SN20D3.1 dengan dosis 200 Gy. Kandungan tanin yang dianjurkan pada buah leunca adalah kandungan tanin yang rendah.

Kata kunci: iradiasi, keragaman, $L D_{50}$, sayuran asli, sinar gamma, tanin

\section{PENDAHULUAN}

Leunca (Solanum nigrum L.) merupakan salah satu sayuran indigenous atau sayuran lokal yang dikonsumsi sebagai obat ataupun sayuran. Setiap $100 \mathrm{~g}$ buah leunca segar mengandung $90 \%$ air, $1.9 \mathrm{~g}$ protein, $0.1 \mathrm{~g}$ lemak, $7.4 \mathrm{~g}$

\footnotetext{
* Penulis untuk korespondensi. e-mail: syarifahiis@yahoo.com
}

karbohidrat, $274 \mathrm{mg} \mathrm{Ca}, 34 \mathrm{mg} \mathrm{Fe}, 0.5 \mathrm{~g}$ karoten, $0.1 \mathrm{mg}$ vitamin B1, dan $17 \mathrm{mg}$ vitamin C (Siemonsma dan Jansen, 1994); (Sarma dan Sarma, 2011). Buah leunca memiliki kandungan steroid yang dapat dimanfaatkan sebagai obat detoks, diuretik, anti hipertensi, antikanker, dan infeksi saluran kemih (Edmonds dan Chweya, 1997). Sebagai sayuran lokal, leunca disebut sebagai sayuran minor, selain belum mampu bersaing dengan sayuran mayor yang telah 
berkembang terlebih dahulu, leunca memiliki rasa yang kurang disukai, terutama oleh anak-anak (Soetiarso, 2010). Senyawa flavour berupa tanin merupakan senyawa yang menimbulkan rasa yang kurang disukai (Gogoi dan Islam, 2012).

Beberapa cara dilakukan dalam memperbaiki sifat tanaman, salah satunya adalah dengan program pemuliaan tanaman dan bioteknologi. Program pemuliaan tanaman melalui induksi mutasi merupakan cara yang dapat dilakukan untuk meningkatkan keragaman dalam memperbaiki sifat tanaman. Aplikasi mutasi dengan iradiasi sinar gamma sudah banyak berhasil dilakukan pada banyak tanaman. Sutjahjo et al. (2014) melaporkan bahwa terdapat keragaman tanaman tomat akibat induksi mutasi. Ivanishvili et al. (2016) melaporkan bahwa efek radiasi yang ditimbulkan dari induksi mutasi mempengaruhi viabilitas dan reproduksi tanaman Lemna. Beberapa penelitian menunjukkan bahwa iradiasi sinar gamma dapat mengubah karakter morfologi tanaman kunyit (Anshori et al., 2014) dan meningkatkan keragaman pada famili Solanum (Ojiewo et al., 2007).

Teknik pemuliaan mutasi yang paling sering dilakukan adalah mutasi fisik karena selain murah juga mempercepat peningkatan keragaman. Ulukapi et al. (2015) melaporkan bahwa persentase pertumbuhan tanaman terong dengan perlakuan induksi mutasi memiliki nilai $\mathrm{LD}_{50}$ yaitu pada dosis 160 Gy. Penelitian ini menseleksi keragaman buah leunca dengan berbagai kandungan tanin sehingga diperoleh rasa yang disukai masyarakat. Dosis iradiasi yang efektif untuk menginduksi keragaman genetik leunca belum diketahui, sehingga pada penelitian ini akan diuji perlakuan iradiasi sinar gamma dengan dosis $0 \mathrm{~Gy}, 100 \mathrm{~Gy}, 150 \mathrm{~Gy}$, $200 \mathrm{~Gy}$, dan $250 \mathrm{~Gy}$.

Nilai LD $_{50}$ bertujuan untuk mengetahui perubahanperubahan yang terjadi pada generasi M1 akibat berbagai tingkat dosis radiasi sinar gamma, sehingga dapat digunakan untuk acuan penelitian induksi mutasi selanjutnya. Rajarajan et al. (2016) melaporkan bahwa mutasi yang dikehendaki umumnya berada pada kisaran Lethal Dose $\left(\mathrm{LD}_{50}\right)$ yaitu dosis yang menyebabkan kematian 50\% tanaman. Penentuan $\mathrm{LD}_{50}$ diperlukan untuk mengetahui dosis yang tepat untuk menghasilkan tanaman mutan. Tujuan penelitian ini adalah untuk menentukan $\mathrm{LD}_{50}$ tanaman leunca, memperoleh informasi tentang keragaan leunca hasil iradiasi sinar gamma dan kandidat mutan leunca dengan kandungan tanin rendah.

\section{BAHAN DAN METODE}

Penelitian dilaksanakan di kebun percobaan Pasir Kuda, Bogor dengan ketinggian $250 \mathrm{~m}$ di atas permukaan laut (dpl). Perlakuan iradiasi dilakukan di Badan Tenaga Nuklir Nasional (BATAN) Pasar Jumat, Jakarta Selatan. Pengamatan kadar tanin dilaksanakan di Laboratorium Pascapanen Pusat Kajian Hortikultura Tropika (PKHT) Institut Pertanian Bogor. Penelitian dilaksanakan pada bulan Desember 2016 hingga Juli 2017.

Bahan percobaan yang digunakan adalah biji leunca aksesi SN 20 dan aksesi SN 29. Populasi tanaman hasil iradiasi disebut generasi M1 dan penanaman musim berikutnya disebut generasi M2. Pada penanaman M1, biji leunca diradiasi dengan menggunakan sinar gamma Cobalt 60 melalui alat irradiator gamma chamber 4000 A. Penelitian disusun menggunakan rancangan kelompok lengkap teracak (RKLT) dengan dosis sebagai perlakuan. Dosis yang digunakan terdiri dari lima taraf dosis yaitu: 0 Gy (kontrol), 100 Gy (D1), 150 Gy (D2), 200 Gy (D3), dan 250 Gy (D4); sehingga total terdapat 500 tanaman membentuk generasi M1. Genotipe leunca generasi M2 ditanam sebanyak 1,000 per genotipe dan di analisis kadar tanin pada masing-masing dosis. Pengamatan dilakukan secara kualitatif dan kuantitatif, karakter kualitatif meliputi bentuk daun dan warna daun. Karakter kuantitatif meliputi tinggi tanaman, umur berbunga, umur panen dan bobot 10 buah per tanaman.

Penentuan $\mathrm{LD}_{50}$ berdasarkan pada persentase tanaman yang tumbuh 6 minggu setelah iradiasi, dengan membuat grafik regresi. Regresi menggunakan software analisis curve fit. Analisis kadar tanin dilakukan pada buah muda generasi M2 mengikuti metode Sulastri (2009) dan Rauf (2016). Senyawa tanin dianalisis menggunakan larutan indigocarmin $\left(\mathrm{C}_{16} \mathrm{H}_{8} \mathrm{~N}_{2} \mathrm{NO}_{2} \mathrm{O}_{8} \mathrm{~S}_{2}\right)$ dan kalium permanganat $\left(\mathrm{KMnO}_{4}\right)$. Sebanyak $10 \mathrm{~g}$ buah leunca diekstrak dan dilarutkan ke dalam $100 \mathrm{~mL}$ ethanol 96\% kemudian dipanaskan di dalam waterbath selama 2 jam pada suhu 60 $65^{\circ} \mathrm{C}$. Ekstrak didinginkan dan disaring kemudian dilakukan pengujian senyawa tanin pada filtrat hasil ekstraksi dengan menambahkan kembali larutan ethanol 96\% pada filtrat hasil ekstraksi hingga tanda batas erlenmeyer $250 \mathrm{~mL}$. Larutan filtrat diambil sebanyak $25 \mathrm{~mL}$ dan dimasukkan ke dalam gelas ukur kemudian ditambahkan $25 \mathrm{~mL}$ larutan indigocarmin, dilanjutkan titrasi dengan larutan $\mathrm{KMnO}_{4}$. Penambahan larutan $\mathrm{KMnO}_{4} 0.1 \mathrm{M}$ saat titrasi dilakukan sampai larutan berubah warna dari biru menjadi hijau, kemudian ditetesi larutan $\mathrm{KMnO}_{4}$ lagi sampai menjadi warna kuning keemasan. Volume titrasi tersebut dinyatakan sebagai A ml. Untuk penetapan larutan blanko dilakukan tanpa filtrat dengan menuang sebanyak $25 \mathrm{~mL}$ ethanol 96\% ke dalam erlenmeyer dan ditambahkan $25 \mathrm{~mL}$ larutan indigocarmin, selanjutnya dilakukan titrasi dengan larutan $\mathrm{KMnO}_{4}$. Volume titrasi blanko dinyatakan sebagai B $\mathrm{mL}$. Analisis kandungan tanin diuji sebanyak 9 sampel tanaman secara acak.

\section{Analisis Data}

Analisis ragam perlakuan dosis diperoleh dengan software SAS 9.0. Perhitungan koefisien keragaman genetik berdasarkan Poehlman dan Sleeper (2006) dengan rumus:

Keterangan:

$$
\mathrm{KKG}=\left(\sqrt{ } \sigma^{2} \mathrm{~g} / \mathrm{X}\right) \times 100 \%
$$

Kriteria koefisien keragaman genetik (KKG) adalah rendah $(0 \% \leq \mathrm{x} \leq 6.60 \%)$, agak rendah $(6.60 \% \leq \mathrm{x} \leq 13.18 \%)$, cukup tinggi $(13.18 \% \leq \mathrm{x} \leq 19.76 \%)$, dan tinggi $(19.76 \%$ $\leq \mathrm{x} \leq 26.35 \%$ ).

Analisis kandungan tanin dengan metode permanganat berdasarkan Rauf (2016) dengan rumus:

$$
\text { Kadar tanin }=\frac{10(A-B) \times N \times 0.004157}{\operatorname{sampel}(g)} \times 100 \%
$$


Keterangan:

$\mathrm{A}=$ Volume titrasi $\operatorname{tanin}(\mathrm{mL}), \mathrm{B}=$ volume titrasi blanko $(\mathrm{mL})$, $\mathrm{N}=$ normalitas $\mathrm{KMnO}_{4}$ standar, $10=$ faktor pengenceran, 1 $\mathrm{mL} \mathrm{KMnO}_{4} 0.1 \mathrm{~N}$ setara dengan $0.004157 \mathrm{~g}$ tanin.

\section{HASIL DAN PEMBAHASAN}

\section{Lethal Dosis 50 Leunca}

Hasil iradiasi sinar gamma pada biji leunca menggunakan Cobalt 60 dapat menentukan radiosensitivitas pada tanaman leunca. Uji radiosensitivitas bertujuan untuk menetapkan dosis $\mathrm{LD}_{50}$, yaitu dosis yang menyebabkan $50 \%$ populasi mengalami kematian akibat iradiasi. Hasil analisis curve fit leunca aksesi SN20 diperoleh model terbaik yang mewakili data kecambah hidup setelah iradiasi yaitu Polynomial Fit dengan persamaan $\mathrm{Y}=79+0.0637667 \mathrm{x}-$ $0.00883 \mathrm{x}^{2}+1.77^{\mathrm{e}-05} \mathrm{x}^{3}$. Berdasarkan model tersebut diperoleh nilai $\mathrm{LD}_{50}$ leunca aksesi SN20 sebesar 171.944 Gy. Hasil analisis curve fit tanaman leunca aksesi SN29 menunjukkan model terbaik untuk mewakili data kecambah hidup setelah iradiasi adalah Polynomial Fit dengan persamaan $\mathrm{Y}=$ $48+0.778 \mathrm{x}-0.01264 \mathrm{x}^{2}+6.32^{\mathrm{E}-05} \mathrm{x}^{3}$ dengan nilai $\mathrm{LD}_{50}$ leunca aksesi SN29 sebesar 190.949 Gy. Nilai LD $_{50}$ setiap aksesi yang diuji mempunyai tingkat kematian pada tanaman yang di radiasi sehingga diperoleh dosis optimum dalam menghasilkan keragaman. Sutapa dan Kasmawan (2016) melaporkan bahwa dosis optimal pada pertumbuhan fisiologis tanaman tomat adalah pada dosis $100 \mathrm{~Gy}$.

\section{Keragaan Mutan Leunca}

Karakter kualitatif pada daun (bentuk dan warna daun) menunjukkan adanya keragaman. Perbedaan bentuk dan warna daun yang mencolok antara tanaman kontrol dan tanaman hasil iradiasi diduga akibat adanya mutasi. Mutasi menyebabkan perubahan bentuk ujung daun terbelah pada dosis 150 Gy dan tekstur daun bergerigi pada dosis 100 Gy. Efek mutasi juga menyebabkan adanya tanaman albino pada dosis 200 Gy (Gambar 1). Tanaman albino ini tidak mampu bertahan dan menghasilkan bunga seperti tanaman kontrol. Albino merupakan keadaan dimana tanaman mengalami kekurangan ataupun kehilangan klorofil daun.
Perubahan fenotipik tanaman akibat mutasi dapat dilihat dari perubahan corak warna dan bentuk daun menjadi beragam. Sari et al. (2015) melaporkan bahwa dosis di atas nilai $\mathrm{LD}_{50}$ menyebabkan respon tanaman gandum menjadi albino pada dosis 30 Gy.

Dosis iradiasi sinar gamma berpengaruh nyata terhadap rata-rata tinggi tanaman dan bobot 10 buah per tanaman generasi M1, tetapi tidak untuk karakter umur berbunga dan umur panen (Tabel 1). Pengaruh perlakuan menyebabkan penurunan tinggi tanaman pada aksesi SN 20 lebih rendah dibanding kontrol, yaitu pada dosis 150 Gy, 200 Gy dan 250 Gy. Pertumbuhan yang lebih rendah juga terdapat pada SN 29 dosis 150 Gy. Bobot 10 buah pertanaman pada aksesi SN 20 untuk semua perlakuan memiliki nilai lebih rendah dibandingkan dengan kontrol dan aksesi SN 29 dosis 150 Gy secara nyata lebih kecil dibandingkan tanaman kontrol. Efek mutasi tidak selalu meningkatkan pertumbuhan tanaman namun juga mengakibatkan gangguan fisiologis akibat mutagen yang diberikan. Meilawati et al. (2016) melaporkan bahwa iradiasi sinar gamma menyebabkan perbedaan secara nyata dan acak pada warna dan bentuk daun tanaman lada.

Pengamatan nilai koefisien keragaman (KK) dilakukan pada generasi M2. Karakter yang diamati menunjukkan adanya keragaman pada karakter tinggi tanaman, tetapi tidak untuk karakter umur panen (Tabel 2). Nilai KK yang tinggi diperlihatkan pada karakter tinggi tanaman aksesi SN 20 dosis 150 Gy, 200 Gy, dan 250 Gy; sebaliknya pada dosis lain nilai KK rendah. Secara keseluruhan, nilai KK umur berbunga leunca mutan M2 tergolong rendah. Nilai KK pada karakter bobot buah aksesi SN 29 secara keseluruhan cukup tinggi, namun pada SN 20 karakter umur berbunga tergolong rendah dan karakter bobot buah agak rendah. Dhanavel et al. (2012) melaporkan bahwa efek mutasi menyebabkan keragaman secara morfologi pada tanaman kacang tunggak. Indriatama et al. (2016) melaporkan bahwa keragaman genetik secara keseluruhan karakter agronomi tanaman gandum tinggi pada generasi M2. Ulukapi et al. (2015) melaporkan bahwa peningkatan dosis sinar gamma mengakibatkan penurunan jumlah daun dan tinggi tanaman pada dosis 240 Gy. Nilai keragaman genetik yang tinggi pada karakter yang diamati memungkinkan dimulainya seleksi populasi leunca pada generasi berikutnya.

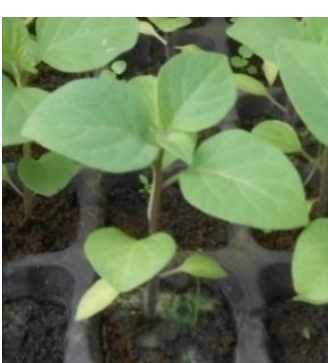

A

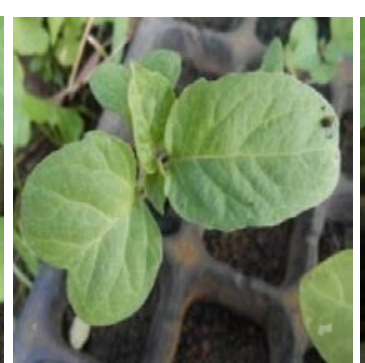

B

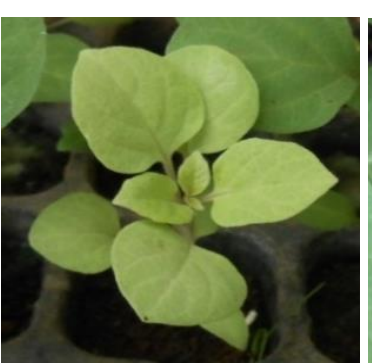

$\mathrm{C}$

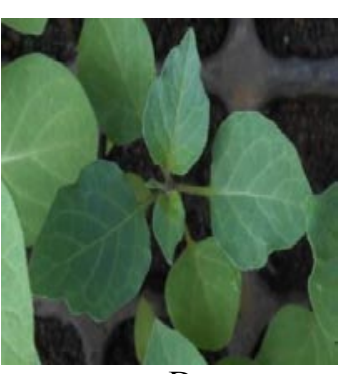

$\mathrm{D}$

Gambar 1. Kandidat mutan daun leunca pada 4 minggu setelah semai (MSS): (A) tanaman kontrol (B) ujung daun terbelah 150 Gy, (C) tanaman albino $200 \mathrm{~Gy}$, (D) tepi daun bergerigi $100 \mathrm{~Gy}$ 
Tabel 1. Keragaan dua aksesi leunca generasi M1

\begin{tabular}{|c|c|c|c|c|c|}
\hline Aksesi & $\begin{array}{l}\text { Dosis } \\
\text { (Gy) }\end{array}$ & $\begin{array}{l}\text { Tinggi tanaman } \\
(\mathrm{cm})\end{array}$ & $\begin{array}{c}\text { Umur berbunga } \\
\text { (HST) }\end{array}$ & $\begin{array}{c}\text { Umur panen } \\
\text { (HST) }\end{array}$ & $\begin{array}{l}\text { Bobot } 10 \text { buah } \\
\text { pertanaman }(\mathrm{g})\end{array}$ \\
\hline \multirow[t]{5}{*}{ SN 20} & 0 & $132.9 a$ & $49.4 a$ & $68.8 b$ & $14.2 \mathrm{a}$ \\
\hline & 100 & $132.6 \mathrm{a}$ & $48.2 \mathrm{a}$ & $77.0 \mathrm{a}$ & $12.8 \mathrm{ab}$ \\
\hline & 150 & $116.7 \mathrm{ab}$ & $48.8 \mathrm{a}$ & $77.6 \mathrm{a}$ & $11.9 b$ \\
\hline & 200 & $100.1 b c$ & $49.4 \mathrm{a}$ & $76.6 \mathrm{a}$ & $10.4 \mathrm{c}$ \\
\hline & 250 & $80.8 \mathrm{c}$ & $49.2 \mathrm{a}$ & $70.2 b$ & $11.7 \mathrm{bc}$ \\
\hline \multirow[t]{5}{*}{ SN 29} & 0 & $109.6 \mathrm{ab}$ & $64.8 \mathrm{a}$ & $78.8 \mathrm{a}$ & $11.1 \mathrm{~b}$ \\
\hline & 100 & $108.6 \mathrm{ab}$ & $64.0 \mathrm{a}$ & $77.4 \mathrm{a}$ & $10.7 b$ \\
\hline & 150 & $89.6 b$ & $65.4 \mathrm{a}$ & $76.4 \mathrm{a}$ & $9.5 \mathrm{c}$ \\
\hline & 200 & $116.6 \mathrm{ab}$ & $65.6 \mathrm{a}$ & $79.2 \mathrm{a}$ & $11.9 \mathrm{a}$ \\
\hline & 250 & $125.0 \mathrm{a}$ & $66.6 \mathrm{a}$ & $76.8 \mathrm{a}$ & $11.1 \mathrm{~b}$ \\
\hline
\end{tabular}

Keterangan: Angka yang diikuti huruf yang sama pada kolom yang sama tidak berbeda nyata berdasarkan Tukey pada $\alpha=5 \%$

Tabel 2. Nilai koefisien keragaman tanaman leunca generasi M2

\begin{tabular}{|c|c|c|c|c|c|c|c|c|c|}
\hline \multirow{2}{*}{ Aksesi } & \multirow{2}{*}{$\begin{array}{c}\text { Dosis } \\
\text { iradiasi } \\
(\mathrm{Gy})\end{array}$} & \multicolumn{2}{|r|}{ TT } & \multicolumn{2}{|c|}{ UB } & \multicolumn{2}{|c|}{ UP } & \multicolumn{2}{|c|}{$\mathrm{BB}$} \\
\hline & & $\mathrm{KK}$ & Kriteria & KK & Kriteria & KK & Kriteria & $\mathrm{KK}$ & Kriteria \\
\hline \multirow[t]{5}{*}{ SN 20} & 0 & 12.67 & Agak rendah & 3.34 & Rendah & 1.57 & Rendah & 12.29 & Agak rendah \\
\hline & 100 & 8.63 & Agak rendah & 2.67 & Rendah & 0.66 & Rendah & 10.53 & Agak rendah \\
\hline & 150 & 29.67 & Tinggi & 7.22 & Agak rendah & 5.97 & Rendah & 4.63 & Rendah \\
\hline & 200 & 23.58 & Tinggi & 3.82 & Rendah & 5.33 & Rendah & 5.20 & Rendah \\
\hline & 250 & 27.92 & Tinggi & 1.11 & Rendah & 5.99 & Rendah & 12.13 & Agak rendah \\
\hline \multirow[t]{5}{*}{ SN 29} & 0 & 12.83 & Agak rendah & 3.07 & Rendah & 0.60 & Rendah & 13.55 & Cukup tinggi \\
\hline & 100 & 8.87 & Agak rendah & 2.58 & Rendah & 3.45 & Rendah & 19.26 & Cukup tinggi \\
\hline & 150 & 5.13 & Rendah & 1.68 & Rendah & 1.51 & Rendah & 15.80 & Cukup tinggi \\
\hline & 200 & 11.52 & Agak rendah & 10.84 & Agak rendah & 2.33 & Rendah & 17.85 & Cukup tinggi \\
\hline & 250 & 4.22 & Rendah & 9.71 & Agak rendah & 5.58 & Rendah & 16.15 & Cukup tinggi \\
\hline
\end{tabular}

Keterangan: $\mathrm{TT}=$ tinggi tanaman; $\mathrm{UB}=$ umur berbunga; $\mathrm{UP}=$ umur panen; $\mathrm{BB}=$ bobot 10 buah per tanaman; $\mathrm{KK}=$ koefisien keragaman $(\%)$

\section{Kadar Tanin Buah Leunca}

Hasil analisis kadar tanin menunjukkan bahwa iradiasi berpengaruh terhadap tinggi rendahnya kadar tanin dalam buah muda dan buah tua. Kadar tanin aksesi buah muda leunca SN20 berkisar antara 0.017-0.097\% dengan kadar tanin tertinggi yaitu pada genotipe SN20D3.5 dosis $200 \mathrm{~Gy}$ sebesar $0.097 \%$, kadar tanin terendah yaitu pada genotipe SN20D4.4 dosis 250 Gy sebesar $0.017 \%$ dan tanaman kontrol sebesar $0.030 \%$ (Gambar 2). Kadar tanin buah muda aksesi SN29 berkisar 0.012-0.055\%, dari hasil diperoleh bahwa kadar tanin tertinggi pada genotipe SN29D3.8 dosis 200 Gy sebesar $0.055 \%$, kadar tanin terendah pada genotipe SN29D1.5 dosis 100 Gy sebesar $0.012 \%$ dan tanaman kontrol sebesar $0.039 \%$ (Gambar 3). Induksi mutasi dengan kadar tanin rendah merupakan kandidat mutan yang diharapkan dari tanaman leunca. Moghaddam et al. (2011) melaporkan

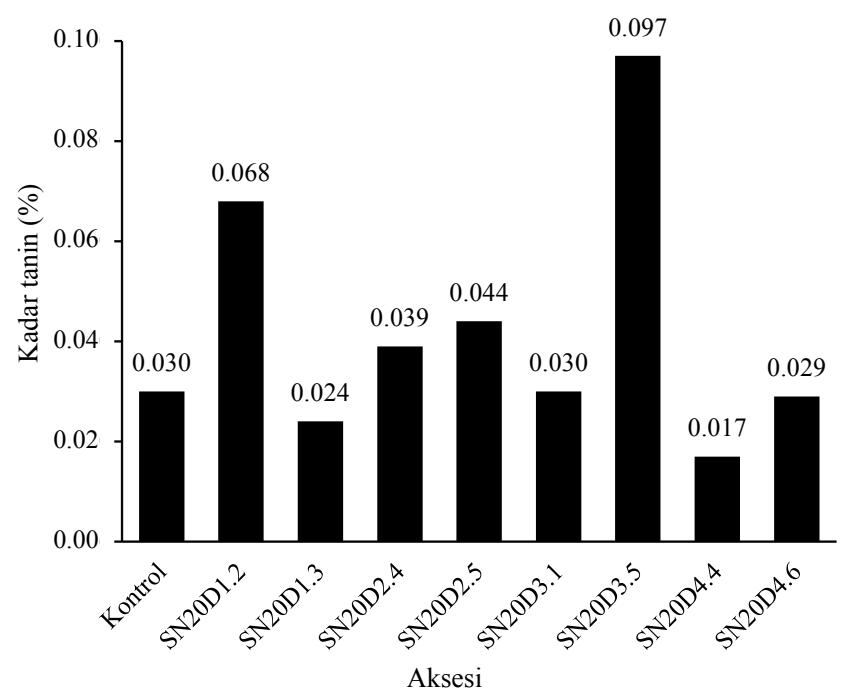

Gambar 2. Persentase kadar tanin buah leunca muda SN20 


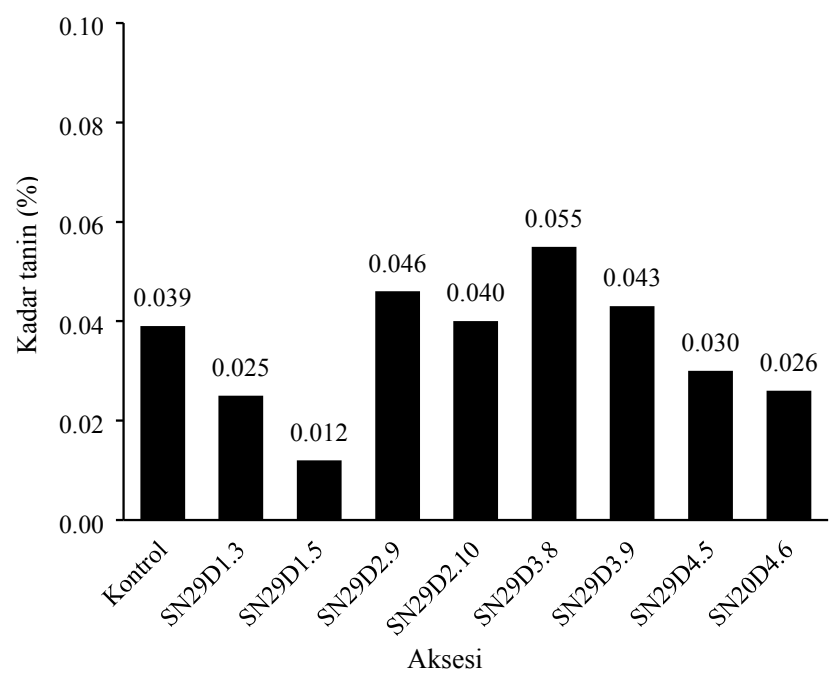

Gambar 3. Persentase kadar tanin buah leunca muda SN29

bahwa efek mutasi dapat mengubah kandungan flavonoid pada Centella asiatica.

Hasil analisis kadar tanin dari buah tua leunca aksesi SN20 berkisar antara 0.005-0.054\% dengan hasil kadar tanin tertinggi yaitu pada genotipe SN20D4.6 dosis 250 Gy sebesar $0.054 \%$, kadar tanin rendah yaitu pada genotipe SN20D3.1 dosis 200 Gy sebesar $0.005 \%$ dan tanaman kontrol sebesar $0.028 \%$ (Gambar 4). Kadar tanin buah tua aksesi SN29 berkisar 0.007-0.050\%, dari hasil diperoleh bahwa kadar tanin tertinggi pada genotipe SN29D3.9 dosis 200 Gy sebesar $0.050 \%$, kadar tanin terendah pada genotipe SN29D2.10 dosis 150 Gy sebesar $0.007 \%$ dan tanaman kontrol sebesar 0.032\% (Gambar 5). Kavitha et al. (2014) melaporkan bahwa terjadi perubahan kandungan antioksidan buah Zizypus mauritiana pada dosis 250 Gy dan 1,000 Gy.

Buah leunca dapat dikonsumsi baik buah muda ataupun buah tua. Tinggi rendahnya kadar tanin antara dosis perlakuan masing-masing nomor individu buah leunca menunjukkan bahwa sifat mutasi dapat mengubah kandungan

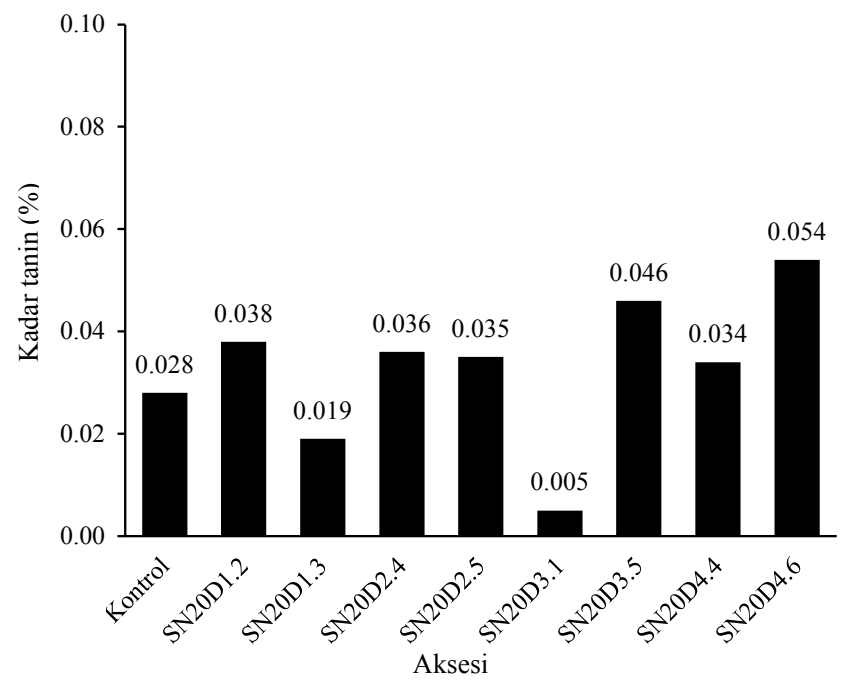

Gambar 4. Persentase kadar tanin buah leunca tua SN20 metabolisme tanaman. Wulandari (2015) melaporkan bahwa kadar tanin pada buah muda pala lebih tinggi dibandingkan buah tua. Kadar tanin juga terlihat berbeda pada kalus daun jati belanda dibandingkan dengan bagian daun jati belanda yang tua (Syahid et al., 2010). Anshori et al. (2014) melaporkan bahwa kerusakan fisiologis menyebabkan perubahan morfologi, perubahan daya adaptasi, dan mutan kondisional tanaman kunyit.

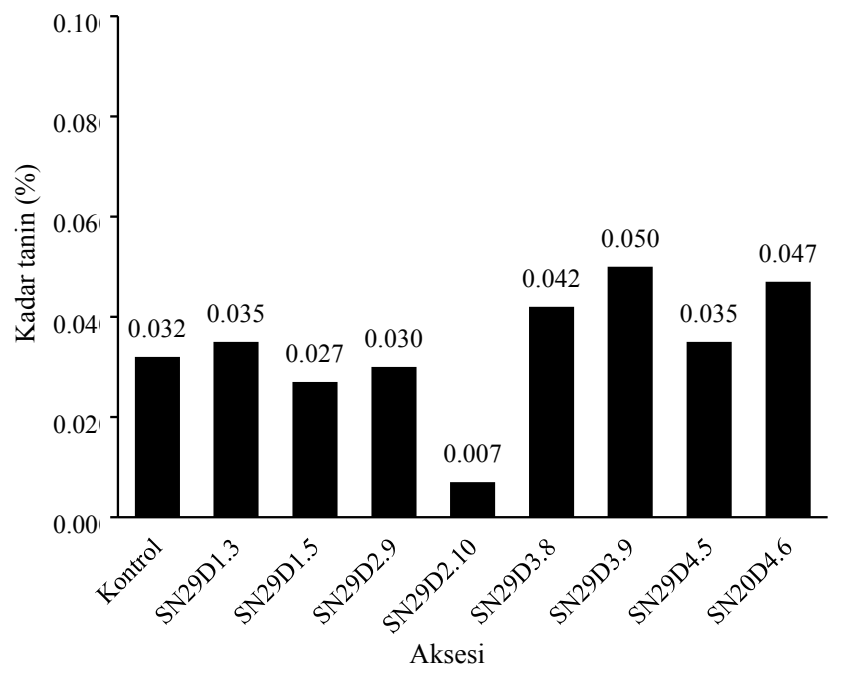

Gambar 5. Persentase kadar tanin buah leunca tua SN29

\section{KESIMPULAN}

Aksesi tanaman yang berbeda memiliki $\mathrm{LD}_{50}$ yang berbeda yaitu genotipe SN20 pada 171.944 Gy dan SN29 pada 190.949 Gy. Iradiasi sinar gamma meningkatkan keragaman pada karakter morfologi yang diamati dan bersifat acak. Iradiasi sinar gamma meningkatkan keragaman kadar tanin pada buah muda aksesi SN20 (0.017-0.097\%), buah muda SN29 (0.012-0.055\%), buah tua SN20 (0.005$0.054 \%)$, dan buah tua SN29 (0.007\%-0.050\%) sehingga memungkinkan untuk mendapatkan buah leunca dengan kadar tanin yang lebih tinggi (0.097\%) maupun kadar tanin yang lebih rendah $(0.005 \%)$ dibandingkan aksesi yang belum diradiasi. Perlakuan iradiasi sinar gamma mampu menghasilkan mutan tanaman leunca yang dikehendaki yaitu buah leunca dengan kadar tanin rendah.

\section{DAFTAR PUSTAKA}

Anshori, S.R, S.I, Aisyah, L.K. Drusman. 2014. Induksi mutasi fisik dengan sinar gamma pada kunyit (Curcuma domestica Val.). J. Hort. Indonesia 5:8494.

Dhanavel, D., S. Gnanamurthy, M. Girija. 2012. Effect of gamma rays on induced chromosomal variation in cowpea Vigna unguiculata (L.) Walp. Int. J. Curr. Sci. 245-250. 
Edmonds, J.M., J.A. Chweya. 1997. Black Nightshades, Solanum ningrum L. and a Related Spesies. International Plant genetic Resources Institute, Australia.

Gogoi, P., M. Islam. 2012. Phytochemical screening of Solanum nigrum L. and S. myriacanthus dunal from districts of Upper Assam, India. IOSR 2:455-459.

Indriatama, W.M., Trikoesoemaningtyas, S.I. Aisyah, H. Soeranto. 2016. Pendugaan ragam genetik dan heritabilitas karakter agronomi gandum (Triticum aestivum L.) hasil berbagai perlakuan teknik iradiasi sinar gamma. J. Ilmiah Aplikasi Isotop Radiasi 12:7988.

Ivanishvili, N.I., M.E. Gogebashvili, N.Z. Gvritishvili. 2016. Gamma radiation efect on the parameters of the population recovery of plants. Ann. Agrarian Sci. 14:319-322.

Kavitha, C., A. Kuna, T. Supraja, S.B. Sagar, T.V.N. Padmavathi, N. Prabhakar. 2014. Effect of gamma irradiation on antioxidant properties of ber (Zizyphus mauritiana) fruit. J. Food. Sci. Technol. DOI 10.1007/ s13197-014-1359-x.

Meilawati, N.L., N. Bermawie, A. Purwito, D. Manohara. 2016. Respon tanaman lada (Piper nigrum L.) varietas cinten terhadap iradiasi sinar gamma. J. Littri 22:71-80.

Moghaddam, S.S., H. Jaafar, R. Ibrahim, A. Rahmat, A.M. Aziz, E. Philip. 2011. Effects of acute irradiation on physiological traits and flavonoid accumulation of Centella asiatica. J. Molecules 16:4994-5007.

Ojiewo, C.O., K. Murakami, P.W. Masinde, S.G. Agong. 2007. Mutation Breeding of African Nightshade (Solanum Section Solanum). Global Science Book. 40-52.

Poehlman, J.M., D.A. Sleeper. 2006. Breeding Field Crops. $4^{\text {th }}$ ed. Iowa State University Press.

Rauf, R.F. 2016. Penggunaan gas karbon dioksida untuk menurunkan kadar tanin buah kesemek (Diospyros kaki L.) kultivar Reundeu. Tesis. Sekolah Pascasarjana. Institut Pertanian Bogor. Bogor.

Rajarajan, D., R. Saraswathi, D. Sassikumar. 2016. Determination of lethal dose and effect of gamma ray on germination percentage and seedling parameters in ADT (R) 47 rice. Int. J. Adv. Biol. Res. 6.328332.
Sari, L., A. Purwito, D. Sopandie, R. Purnamaningsih, E. Sudarmanowati. 2015. Pengaruh irradiasi sinar gamma pada pertumbuhan kalus dan tunas tanaman gandum (Triticum aestivum L.). J. Ilmu Pertanian 18:44-50.

Sarma, H., A. Sarma. 2011. Solanum ningrum L., a nutraceutical enriched herb or invasive weed. Int. Conf. on Env. and Bio (IPCBEE). 21:106-109

Siemonsma, J.S., P.C.M. Jansen. 1994. Solanum americanum Miller. Dalam Siemonsma, J.S., K. Piluek (Ed.). Plant Resources of South-East Asia 8:252-255.

Soetiarso, T.A. 2010. Persepsi dan preferensi konsumen terhadap atribut produk beberapa jenis sayuran minor. J. Hort. 20:299-312.

Sulastri, T. 2009. Analisis kadar tanin ekstrak air dan ekstrak etanol pada biji pinang sirih (Areca catechu L.). J. Chemica. 10:59-63.

Sutapa, G.N., I.G.A. Kasmawan. 2016. Efek induksi mutasi radiasi gamma ${ }^{60} \mathrm{Co}$ pada pertumbuhan fisiologis tanaman tomat (Lycopersicon esculentum L.). J. Keselamatan Radiasi dan Lingkungan 1:5-11.

Sutjahjo, H.S., K.H. Muttaqin, L.P. Ekowahyuni, S. Marwiyah. 2014. Induksi Keragaman Genetik Tomat Lokal Melalui Iradiasi Sinar Gamma. Prosiding Seminar Hasil PPM IPB 2014.

Syahid, S.F., N.N. Kristina, D. Seswita. 2010. Pengaruh komposisi media terhadap pertumbuhan kalus dan tannin dari daun jati belanda (Gauzuma ulmifolia L.) secara in vitro. J. Littri 16:1-5.

Togatorop, E.K., S.I. Aisyah, M.R.M. Damanik. 2016. Pengaruh mutasi fisik iradiasi sinar gamma terhadap keragaman genetik dan penampilan Coleus blumei. J. Hort. Indonesia 7:187-194.

Ulukapi, K., B. Ozdemir, A.N. Onus. 2015. Determination of proper gamma radiation dose in mutation breeding in eggplant (Solanum melongena L.). Adv. Environ. Agric. Sci. 149-153.

Wulandari, A. 2015. Pemetaan karakteristik kimia, fisik, sensori dan fungsional beberapa jenis pala (Myristica spp.). Skripsi. Institut Pertanian Bogor. Bogor 